Egyptian Journal of Rabbit Science, 27 (2): 399- 412(2017)

\title{
EFFECT OF FASTING PERIOD AND ZINC SUPPLEMENTATION ON THYROID AND ADRENAL ACTIVITY, ANTIOXIDANT STATUS AND GUT LENGTH OF GROWING RABBITS
}

\author{
M.E. El-Speiy ${ }^{1}$;El-Sawy ${ }^{1}$, M.A.; F.B.A., Badri ${ }^{2}$ and T.A. Sadaka ${ }^{1}$ \\ ${ }^{1}$ Animal Prod. Res. Institute, Agric. Res. Center, Ministry of Agric., Egypt. \\ ${ }^{2}$ Poultry Production Department, Faculty of Agric., Ain-Shams Univ., Cairo, \\ Egypt. E-mail:Elsawv1966@Gmail.com
}

Ninety weaned males V-line rabbits (35 days old) with an average live body weight of $525 \pm 8.34 \mathrm{~g}$. were randomly distributed into six experimental groups $(n=15$ each). All treated groups were received a basal diet; $1^{\text {st }}$ experimental group was served as control group (AD), $2^{\text {nd }}$ group was supplemented with $Z n(A D+Z n), 3^{\text {rd }}$ group was fasted one day weekly (F24), $4^{\text {th }}$ group was fasted two days weekly (F48), $5^{\text {th }}$ group was supplemented with Zn and fasted one day weekly $(F 24+Z n)$ and $6^{\text {th }}$ group was supplemented with $\mathrm{Zn}$ and fasted two days weekly $(F 48+Z n)$. Serum concentrations of $T_{3}, T_{4}$, corticosterone, cortisol, total antioxidant capacity $(T A C)$ and malonyaldehyde (MAD) were determined. Lengths of small and large intestine and caecum were measured.

Results showed that: highly significant increase in serum levels of cortisol and corticosterone hormones were recorded in fasted growing rabbits (F24 and F48) groups and fasted with Zinc supplementation $(F 24+Z n$ and $F 48+Z n)$ groups, while serum levels of $T_{3}$ and $T_{4}$ were decreased compared with those in $A D$ and $A D+Z n$ groups. Serum level of TAC was significantly reduced in fasted growing rabbits supplemented or non-supplemented with Zn compared with $A D$ and $A D+Z n$ groups and more reduction was related to fasting. Deleterious effect of fasting was related with increasing serum levels of $M A D$, where all fasted groups had a significant increase in serum $M A D$ concentration. Length of stomach, small and large intestines and caecum was significantly increased in fasted and $\mathrm{Zn}$ treated groups than control group.

Conclusively, fasting regimen and dietary Zn supplementation had a role in modulating hormonal profile, antioxidant status, stomach and intestine length.

Key words: Fasting, Zinc, hormonal profile, digestive tract length, 
Kit's rabbit exposed to stressful trouble on digestive tract and microbial count as soon as change feed to solid phase and abstention to suckling. Weaning stage is a critical phase during the development of digestive tract and digestive disorders caused by insufficient development of digestive enzymatic capability at an early age. Moreover, the weaning and the post weaning period are particularly important for the growth and feed efficiency (De Blas, 2013 and Tůmová et al., 2016). Debray et al., (2003) recorded that the quantitative feed regimen and period restriction for rabbits reduce the incidence of digestible disorders. Gidenne et al., (2012) stated that the absorption of nutrients depends on gut status. Also, quantitative and period of feed restriction can modify the morphology of the small intestine mucosa. Absorption may be affected by changing in the small intestine length an entire spectrum of mucosal changes, that containing the amount of villi extending into the lumen. Moreover, feed restriction might positively affect the several changes on metabolic disorders that lead to hormonal changes, immune depression and alter the digestive system functions, especially the liver and small intestine (Tůmová et al., 2016). Furthermore, fasting period could rapidly restore the morphology and functions of the intestine (Maria et al., 2013). Increasing the endogenous production of adrenal corticoids from the adrenal glands, following the action of stress factors such as fasting was demonstrated (Kock et al., 1987). Zinc is a vital trace element that plays an essential role in several biological functions such as protein and DNA synthesis, metabolic activities and growth (Tapiero and Tew, 2003). Dietary $\mathrm{Zn}$ has an important component for hormonal functions and special physiological process including catalytic, structural and regulatory activities in which they interact with macromolecules such as enzymes, pro-hormones, pre-secretory granules and biological membranes (Alikwe et al., 2011).

Therefore, the aim of the present study was performed to evaluate the influence of fasting period and dietary zinc supplementation on thyroid and adrenal activities, antioxidant status and morphological changes of digestive tract of growing rabbit.

\section{MATERIALS AND METHODS}

\section{Housing and management:}

This work was carried out at a Private Rabbit Farm at Qaluobia Governorate, during the period from February to April 2017. 
Ninety weaned males V-line rabbits (35 days old) with an average live body weight of $525 \pm 8.34 \mathrm{~g}$. were randomly distributed into six experimental groups ( $\mathrm{n}=15$ each) (Table 1$)$. Rabbits were housed in a naturally ventilated building and kept in individual wire galvanized battery. The basal diet was formulated to meet the recommended nutrient requirements of growing rabbits according to De Blas and Mateos (1998). They were allowed to a standard pellet diet (17\% crude protein, $2.56 \%$ crude fat and $2500 \mathrm{Kcal} / \mathrm{kg}$ ration DE and $13 \%$ crude fiber). Feed and water were available ad libitum. The lighting program provided $16 \mathrm{~h}$ of light per day.

Table 1. Experimental design

\begin{tabular}{|c|c|c|c|}
\hline $\begin{array}{c}\text { Treatment } \\
\text { groups }\end{array}$ & Basal diet plus & \multicolumn{2}{|c|}{ Fasting } \\
\hline $\mathrm{AD}$ & -- & -- & -- \\
\hline $\mathrm{AD}+\mathrm{Zn}$ & $\mathrm{Zn}{ }^{* *}$ & -- & -- \\
\hline $\mathrm{F} 24$ & -- & Sunday & -- \\
\hline $\mathrm{F} 48$ & -- & Sunday & Thursday \\
\hline $\mathrm{F} 24+\mathrm{Zn}$ & $\mathrm{Zn}$ & Sunday & -- \\
\hline $\mathrm{F} 48+\mathrm{Zn}$ & $\mathrm{Zn}$ & Sunday & Thursday \\
\hline
\end{tabular}

** Zinc was added as a $\mathrm{ZnSO}_{4}(100 \mathrm{mg} \mathrm{Zn} / \mathrm{kg}$ diet $)$, purchased from ElGomhoria for chemical Company, Cairo, Egypt.

\section{Blood samples:}

At the end of experiment ( 84 days of age), blood samples were obtained from the ear vein using $3 \mathrm{ml}$ syringe, centrifuged at 3000 r.p.m. for $20 \mathrm{~min}$., serum was collected and stored at $-20^{\circ} \mathrm{C}$ until analyses.

\section{Hormonal assay:}

Serum concentrations of thyroxin $\left(\mathrm{T}_{4}\right)$ and triiodothyronine $\left(\mathrm{T}_{3}\right)$ were measured according to Abdel-Fattah et al., (2011) using radioimmunoassay (RIA) technique. Blood serum concentrations of corticosterone and cortisol were measured using RIA, using the CORT kit (ICN Biomedical Inc., Costa) according to Palme et al., (1996).

\section{Antioxidative status:}

Total antioxidant capacity (TAC) and malonyaldehyde (MAD) were measured according to Koracevic et al., (2001) and Richard et al., (1992), respectively.

\section{Gastrointestinal measurements:}

At the end of experiment, rabbits were slaughtered, eviscerated and the 
length of small and large intestine and caecum were measured. Small intestine was measured from duodenum to junction of ileum, caecum (without appendix), and colon, large intestine involved proximal and distal colon.

\section{Statistical analysis:}

Data were subjected to ANOVA using the general linear models procedure of SAS (2002) as following model:

$$
\mathrm{Y}_{\mathrm{ij}}=\mu+\mathrm{T}_{\mathrm{i}}+\mathrm{e}_{\mathrm{ij}}
$$

Where: $Y_{i j}=$ An observation; $\mu=$ Overall mean; $T_{i}=$ Treatment effect, and $e_{i j}=$ Experimental error. When significant differences among means were tested by using Duncan's multiple rang test (Duncan, 1955).

\section{RESULTS AND DISCUSSION}

\section{Effect of fasting and zinc supplementation on:}

\section{1-Thyriod and adrenal hormones:}

Results concerning the effect of fasting regimen and dietary $\mathrm{Zn}$ supplementation on serum glucocorticoid hormones and thyroid hormones concentrations in growing rabbits are presented in Table 2. It is noteworthy to note that growing rabbits exposed to fasting (F24, F48, F24+Zn and F48+Zn groups) had a significant increase in serum levels of cortisol and corticosterone compared with those in control groups ( $\mathrm{AD}$ and $\mathrm{AD}+\mathrm{Zn}$ ). These results are in agreement with Zhang et al., (2011) who reported that plasma corticosterone is considered the main glucocorticoid involved in regulation of stress responses in rodents (eg, heat stress, fasting,..etc), serum cortical hormones level can be used as an indicator for activation of stress in rabbits. Cortisol secretion is a generic response to stress as well as a specific adaptive response to fasting and nutritional stress. Wu et al., (2012) observed that the plasma corticosterone concentration in mice subjected to chronic stress was significantly higher than control. Also, Liu et al., (2013) observed a significant increase of corticosterone levels in mice following $24 \mathrm{~h}$ of acute restraint stress.

As shown in Table 2, fasting regimen and fed diet supplemented with or without Zn (F24, F48, F24+Zn and F48+Zn groups) had significantly decrease in blood serum $T_{3}$ and $T_{4}$ compared with those in non fasting groups $(\mathrm{AD}$ and $\mathrm{AD}+\mathrm{Zn})$.

It is well known that feed restriction is involved in the regulatory mechanisms of metabolism in animals. In this context, Suda et al., (1978) recorded that calorie deprivation leads to reduction in serum $\mathrm{T}_{3}$ is caused by a 
reduction from $T_{4}$ rather than by an acceleration in its metabolic clearance rate. The decrease in $\mathrm{T}_{3}$ concentration is accompanied by a concomitant and reciprocal change in the concentration of total and free $\mathrm{T}_{3}$. Rommers et al., (2002) reported that long-term nutrient deficiency during development has major neuro-endocrine consequences trigger prominent homeostatic reactions of the corticotrophin, somatotropic and thyrotrophic axes. Chan et al., (2006) reported that fasting $72 \mathrm{~h}$ caused to decrease a significant in free $\mathrm{T}_{3}$, and increased reverse $T_{3}$, whereas free $T_{4}$ remained stable.

Zinc may play a role in thyroid hormones metabolism. Maxwell and Volpe (2007) reported that $\mathrm{Zn}$ supplementation appeared to have a favorable effect on thyroid hormones levels, particularly total $\mathrm{T}_{3}$. Moreover, Ertek et $a l$. , (2010) showed that $\mathrm{Zn}$ levels were significantly positively correlated with free $\mathrm{T}_{3}$ levels. Similarly, Zearah et al., (2016) showed that the elevation of total $\mathrm{T}_{4}$ and total $\mathrm{T}_{3}$ levels after the intake of $\mathrm{Zn}$ supplementation.

\section{2-Antioxidant status:}

Respecting to the influence of fasting regimen and dietary $\mathrm{Zn}$ supplementation on serum TAC and MAD (Table 2), it could be noted that TAC was significantly increased in the group fed diet supplemented with $\mathrm{Zn}$ $(\mathrm{AD}+\mathrm{Zn})$ compared with the other experimental groups. However, TAC was significantly reduced in growing rabbit subjected to fasting regimen ( 24 or $48 \mathrm{~h}$ ) and dietary $\mathrm{Zn}$ supplementation alleviated this effect and improved TAC significantly. It is noteworthy to indicate that growing rabbits exposed to fasting (F24, F48, F24+Zn and F48+Zn groups) had a significant increase in serum MAD concentration which used as lipid peroxidation index; however, the lowest value was recorded for the group fed basal diet supplemented with $\mathrm{Zn}$ $(\mathrm{AD}+\mathrm{Zn})$. One of $\mathrm{Zn}$ important functions is participation in the antioxidant defense system (Powell, 2000). Oxidative stress is manifested primarily via changes of antioxidant enzyme activities and the reductions of some nonenzymatic antioxidants. Bun et al., (2011) noted that activities of superoxide dismutase and glutathione peroxidase were increased with increasing dietary $\mathrm{Zn}$ levels in broiler chickens, while, lipid peroxidation tended to be reduced at $\mathrm{Zn}$ inclusion of 20 and $40 \mathrm{mg} / \mathrm{kg}$ diet.

Shaheen and Abdel-Fattah (1995) reported that $\mathrm{Zn}$ deficiency caused increased lipid peroxidation and that this was overcome by $\mathrm{Zn}$ supplementation. Juda et al., (2009) found that orally Zn supplementations significantly decrease in serum concentration of MAD in comparison with control. Duzgunerand Kaya (2007) concluded that daily $\mathrm{Zn}$ supplementation could reduce the harmful effects of oxidative (by reduce MAD) stress in diabetics rabbit. 
Table 2. Effect of fasting and dietary $\mathrm{Zn}$ supplementation on hormonal profile and antioxidants status of growing $\mathrm{V}$-line male rabbits at 84 days of age.

\begin{tabular}{|c|c|c|c|c|c|c|}
\hline Treatments & $\begin{array}{c}\text { Cortisol } \\
\text { (ug/dl) }\end{array}$ & $\begin{array}{c}\text { Corticosterone } \\
(\mathbf{n m o l} / \mathbf{m l})\end{array}$ & $\begin{array}{c}\mathbf{T}_{\mathbf{3}} \\
(\mathbf{n g} / \mathbf{m l})\end{array}$ & $\begin{array}{c}\mathbf{T}_{\mathbf{4}} \\
(\mathbf{u g} / \mathbf{d l})\end{array}$ & $\begin{array}{c}\text { TAC } \\
(\mathbf{m M} / \mathbf{L})\end{array}$ & $\begin{array}{c}\text { MAD } \\
(\mathbf{n m o l} / \mathbf{m l})\end{array}$ \\
\hline Control, AD & $5.20^{\mathrm{d}}$ & $5.25^{\mathrm{d}}$ & $2.20^{\mathrm{b}}$ & $4.43^{\mathrm{b}}$ & $125.87^{\mathrm{b}}$ & $59.03^{\mathrm{c}}$ \\
& \pm 0.33 & \pm 0.08 & \pm 0.22 & \pm 0.09 & $\pm 0.52^{2}$ & \pm 1.75 \\
\hline $\mathbf{A D}+\mathbf{Z n}$ & $4.53^{\mathrm{de}}$ & $5.05^{\mathrm{d}}$ & $2.70^{\mathrm{a}}$ & $5.87^{\mathrm{a}}$ & $135.23^{\mathrm{a}}$ & $47.93^{\mathrm{d}}$ \\
& \pm 0.15 & \pm 0.07 & \pm 0.07 & \pm 0.22 & $\pm 0.48^{\mathrm{c}}$ & \pm 0.80 \\
\hline $\mathbf{F 2 4}$ & $8.23^{\mathrm{b}}$ & $7.18^{\mathrm{b}}$ & $1.50^{\mathrm{cd}}$ & $1.80^{\mathrm{e}}$ & $98.20^{\mathrm{d}}$ & $67.67^{\mathrm{b}}$ \\
& \pm 1.95 & \pm 0.06 & \pm 0.09 & \pm 0.04 & \pm 0.79 & \pm 1.11 \\
\hline $\mathbf{F 4 8}$ & $10.87^{\mathrm{a}}$ & $7.88^{\mathrm{a}}$ & $1.23^{\mathrm{d}}$ & $1.57^{\mathrm{e}}$ & $88.07^{\mathrm{e}}$ & $78.10^{\mathrm{a}}$ \\
& \pm 0.16 & \pm 0.02 & \pm 0.10 & \pm 0.06 & \pm 0.97 & \pm 1.34 \\
\hline F24+Zn & $6.83^{\mathrm{bc}}$ & $6.52^{\mathrm{c}}$ & $1.80^{\mathrm{c}}$ & $2.73^{\mathrm{c}}$ & $118.63^{\mathrm{bc}}$ & $68.90^{\mathrm{b}}$ \\
& \pm 0.13 & \pm 0.06 & \pm 0.10 & \pm 0.06 & \pm 0.99 & \pm 1.90 \\
\hline F48+Zn & $6.93^{\mathrm{bc}}$ & $7.08^{\mathrm{b}}$ & $1.43^{\mathrm{cd}}$ & $2.23^{\mathrm{d}}$ & $108.37^{\mathrm{c}}$ & $67.93^{\mathrm{b}}$ \\
& \pm 0.24 & \pm 0.06 & \pm 0.34 & \pm 0.06 & \pm 1.02 & \pm 1.59 \\
\hline Sig & $* *$ & $* *$ & $* *$ & $* *$ & $* *$ & $* *$ \\
\hline
\end{tabular}

a,b,c,d Means with different superscripts in the same column differ significantly $(\mathrm{P} \leq 0.01)$., $\mathbf{T}_{3}=$ Triiodothyronine, $\mathbf{T}_{4}=$ Thyroxin, $\mathbf{T A C}=$ Total antioxidant capacity, $\mathbf{M A D}=$ Malonylaldhyed .

\section{3- Gastrointestinal tract measurements:}

Table 3 shows the overall means of relative length and weight percentage of digestive tract in rabbit slaughtered at 84 days of age. Data revealed that growing rabbits fed $\operatorname{diet}+\mathrm{Zn}(\mathrm{AD}+\mathrm{Zn})$ and those subjected to feeding regimen and consumed diet with or without $\mathrm{Zn}$ (F24, F48, F24+Zn and $\mathrm{F} 48+\mathrm{Zn}$ groups) had a significant increase in length and percentage of studied digestive tract parts. There was a great variant in the results found in the literature, probably due to the differences in the restriction level, duration and period when feeding regimen was performed. Domestic rabbits are herbivores, concentrate selectors, and are classified as hindgut fermentors (Cheeke, 1987 and McNitt et al., 1996).The rabbit caecum is very large, compared with the rest of the gut (Stevens and Hume, 1995) and forms a spiral shape that fills the abdominal cavity. The caecum (Jenkins, 1999) has a capacity 10 times that of the rabbit's stomach. Mazeti and Furlan (2008) verified a higher relative weight and length of small intestine in regimen animals compared with control. Maria et al., (2013) revealed that rabbits fed ad libitum or restricted diets from 33 to 40 days of age showed higher villus and villus perimeter. Also, rabbits restricted from 33 to 40 days had larger 
villus and higher absorption surface $(\mathrm{P}<0.01)$ than the non-restricted rabbits or the ones restricted from 54 to 61 days. In the same respect, On the other hand, Tůmová et al., (2007) demonstrated that feeding regimen reduced the intestine weight and size, but one week after re-feeding, intestine weight had increased, at the end of the experiment there was no difference in weight among the animals, but the small intestine was longer in rabbits fed ad libitum. Also, Wijtten et al., (2010) reported that feeding regimen can result in lower villus perimeter and lower crypt depth, in addition to decreasing the enzymatic activity in the enterocytes.

However, Southon et al., (1986) reported that $\mathrm{Zn}$ deficiency caused impairment of gut architecture and organelles, such as shorter and narrower jejunal villi, reduced absorptive surface area, decreased number of mitochondria, swelling of the endoplasmic reticulum and atrophic Golgi apparatus, accompanied by increased membrane permeability and declined cell mobility. Also, Zn deficiency decreased the number of goblet cells and mucus thickness, inhibited mucin synthesis, which resulted in colonization by pathogenic microorganisms, penetration of mucus layer, and finally infectious diseases (Quarterman et al., 1976 and Quarterman 1987). Also, Liu et al., (2013) concluded that dietary Zn supplementation caused changes in colonic morphology, mucin profiles and immunological parameters in piglets after weaning. Starvation induces intestinal epithelial atrophy, which is more closely associated with increased epithelial cell apoptosis (Song et al., 2011).

According to the literatures, food regimen (starvation or fasting) caused increased concentration of corticosterone hormone, including increase the expression of sodium glucose co-transporter 1 (SGLT1) and peptide transporter 1 (PepT1) mRNA in the small intestine of chickens and rats (Naruhashi et al., 2002). All kinds of stressors exist around broiler chickens can be mimicked by glucocorticoids (such as corticosterone) (Lin et al., 2007). Hu and Guo, (2008) revealed that corticosterone administration decreased feed intake and duodenal and jejunal epithelial cell proliferation of young broilers. Villus height is positively related to villus surface area (Mitchell and Carlisle, 1992); reduction of villus height during villus growth would decrease the expansion of small intestinal surface area and subsequently decrease the absorptive capacity (Moran, 1985). 
Table3. Effect of fasting days and dietary Zn supplementation on lengths of the digestive tract of growing $\mathrm{V}$-line male rabbits at 84 day of age.

\begin{tabular}{|c|c|c|c|c|}
\hline Treatments & $\begin{array}{c}\text { Stomach } \\
(\mathbf{c m})\end{array}$ & $\begin{array}{c}\text { Small intestine } \\
(\mathbf{c m})\end{array}$ & $\begin{array}{c}\text { Large intestine } \\
(\mathbf{c m})\end{array}$ & $\begin{array}{c}\text { Caecum } \\
(\mathbf{c m})\end{array}$ \\
\hline Control, AD & $9.72^{\mathrm{d}}$ & $228.60^{\mathrm{d}}$ & $88.967^{\mathrm{c}}$ & $9.20^{\mathrm{c}}$ \\
& \pm 0.01 & $\pm 0.56^{\mathrm{a}}$ & \pm 0.58 & \pm 0.16 \\
\hline $\mathbf{A D}+\mathbf{Z n}$ & $10.59^{\mathrm{a}}$ & $281.33^{\mathrm{a}}$ & $170.30^{\mathrm{a}}$ & $12.40^{\mathrm{a}}$ \\
& \pm 0.04 & $\pm 0.41^{\mathrm{a}}$ & \pm 0.29 & \pm 0.24 \\
\hline $\mathbf{F 2 4}$ & $10.09^{\mathrm{c}}$ & $246.33^{\mathrm{c}}$ & $144.30^{\mathrm{b}}$ & $9.70^{\mathrm{c}}$ \\
& \pm 0.02 & $\pm 0.56^{\mathrm{b}}$ & \pm 0.66 & \pm 0.12 \\
\hline $\mathbf{F 4 8}$ & $9.99^{\mathrm{c}}$ & $243.00^{\mathrm{c}}$ & $139.13^{\mathrm{b}}$ & $10.07^{\mathrm{c}}$ \\
& \pm 0.01 & $\pm .71^{\mathrm{b}}$ & \pm 0.64 & \pm 0.16 \\
\hline $\mathbf{F 2 4 + Z n}$ & $10.49^{\mathrm{ab}}$ & $253.67^{\mathrm{b}}$ & $141.13^{\mathrm{b}}$ & $10.90^{\mathrm{b}}$ \\
& \pm 0.05 & $\pm 0.56^{\mathrm{b}}$ & \pm 0.39 & \pm 0.21 \\
\hline $\mathbf{F 4 8 + Z n}$ & $10.41^{\mathrm{b}}$ & $257.67^{\mathrm{b}}$ & $143.90^{\mathrm{b}}$ & $10.43^{\mathrm{bc}}$ \\
& \pm 0.07 & \pm 0.67 & \pm 0.65 & \pm 0.24 \\
\hline Sig & $* * *$ & $* * *$ & $* * *$ & $* * *$ \\
\hline
\end{tabular}

$a, b, c, d$ Means with different superscripts in the same column differ significantly $(P \leq 0.001)$.

Conclusivly, fasting regimen and dietary $\mathrm{Zn}$ had a role in modulating hormonal profile of thyroid and adrenal glands, antioxidant status and digestive tract length in growing rabbits.

\section{REFERENCES}

Abdel-Fattah. A.A.; K.M. Sallam and K.A. Moustafa (2011). A novel method for determination of $\mathrm{T}_{3}$ and $\mathrm{T}_{4}$ hormones, associated with its physicochemical studies. Radiochemistry, 53: 213-220.

Alikwe, P.C.N.; T. Ojiezeh and S. Olagboye (2011). Effects of zinc supplement on rabbits performance and growth rate. Journal of Agriculture and Social Research (JASR), 11(2), P: 46-50.

Bun, S.D.; Y.M. Guo; F.C. Guo; F.J. Ji and H. Cao (2011). Influence of organic zinc supplementation on the antioxidant status and immune responses of broilers challenged with Eimeriatenella. Poultry Sci., 90: 1220-1226. 
Chan, J.L., G. Matarese; G.K. Shetty; P. Raciti; I.K. Aufiero; V.D. Rosa; F. Perna, S. Fontana and C.S. Mantzoros (2006). Differential regulation of metabolic, neuroendocrine, and immune function by leptin in humans. PNAS., 103(22): 8481-8486.

Cheeke, P. R. (1987). Rabbit Feeding and Nutrition. Academic Press, WashingtonD.C., USA.

De Blas, J.C. (2013). Nutritional impact on health and performance in intensively reared rabbits. Animal, 7: 102-111.

De Blas, J.C. and G.G. Mateos (1998). Feed Formulation. In: De Blas J.C., Wiseman J. (Ed). CABI Publishing, UK, 241-254.

Debray, L.; I.Le Huerou-Luron; T.Gidenne and L. Fortun-Lamothe (2003). Digestive tract development in rabbit according to dietary energetic source: correlation between whole tract digestion, pancreatic and intestinal enzymatic activities. Comp. Biochem. Physiol., 135: 443-455.

Duncan, D. B. (1955). Multiple range and multiple F tests. Biometrics, 11:1-42.

Duzguner, V. andS. Kaya (2007). Effect of zinc on the lipid peroxidation and the antioxidant defense systems of the alloxan-induced diabetic rabbits. Free Radic. Biol. Med., 42(10): 1481-1486.

Ertek, S.1.; A.F. Cicero; O. Caglarand G. Erdogan (2010). Relationship between serum zinc levels, thyroid hormones and thyroid volume following successful iodine supplementation. Hormones (Athens). 9 (3): 263-268.

Gidenne, T.; S. Combes and L. Fortun-Lamothe (2012). Feed intake limitation strategies for the growing rabbit: effect on feeding behaviour, welfare, performance, digestive physiology and health: A review. Animal, 6: 1407-1419.[PubMed]

Hu, X.F. and Y.M. Guo (2008). Corticosterone administration alters small intestinal morphology and function of broiler chickens. Asian-Aust. J. Anim. Sci., 21: 1773-1778.

Jenkins, J.R. (1999). Feeding recommendations for the house rabbit. Veterinary clinics of North America: Exotic Animal practice, VOL. 2, Saunders W.B. Company, Philadelphia, pp143.

Juda, T.M.; M.J. Ewad; K.J. Alhamdani and M.R. Judy (2009). Role of oxidative stress by lipid peroxidation in developing urinary bladder cancer and correlation between malondialdehyde and trace elements copper and zinc. Medical Journal of Babylon, 6(1): 45-53. 
Kock, M.D.; R.K. Clark; C.E. Franti; D.A. Jessup and J.D. Wehausen (1987). Effects of capture on biological parameters in free-ranging bighorn sheep (Oviscanadensis): evaluation of normal, stressed and mortality outcomes and documentation ofpostcapture survival. J. Wildly Dis., 23(4): 652-662.

Koracevic, D.; G. Koracevic; V. Djordjevic; S. Andrejevic andV. Cosic (2001). Method for the measurement of antioxidant activity in human fluids. J. Clin. Pathol., 54: 356-361.

Lin, H.; S.J. Sui; H.C. Jiao; K.J. Jiang; J.P. Zhao and H. Dong (2007). Effects of diet and stress mimicked by corticosterone administration on early postmortem muscle metabolism of broiler chickens. Poultry Sci., 86B:545-554.

Liu, Y.; X. Zhuang; L. Gou; X. Ling and X. Tian (2013). Protective effects of nizofenone administration on the cognitive impairments induced by chronic restraint stress in mice. Pharmacol. Biochem. Behav., 103: 474480.

Maria, C. Oliveira; D.M. Silva; D.M. Dias (2013). Effect of feed restriction on organs and intestinal mucosa of growing rabbits, R. Bras. Zootec., Vol.42(7) Viçosa July http://dx.doi.org.

Maxwell, C.1. and S.L.Volpe (2007). Effect of zinc supplementation on thyroid hormone function. A case study of two college females. Ann. Nutr. Metab., 51(2): 188-94.

Mazeti, C.M. and M.D.P. Furlan (2008). Crescimentoe parâmetros reprodutivos de ratas Wistar, emrestriçãoalimentardesde o nascimento. ActaScientirarum Biological Science, 30: 197-204.

McNitt, J.I.; Cheeke, P.R.; Patton, N.M. and Lukefahr, S.D. (1996). Rabbit Production. Interstate publishers Inc., Danville, IL.

Mitchell, M.A. and A.J. Carlisle (1992). The effect of chronic exposure to elevated environmental temperature on intestinal morphology and nutrient absorption in the domestic fowl (Gullusdomesticus). Comp. Biochem. Physiol., 101A: 137-142.

Moran, E.T. (1985). Digestion and absorption of carbohydrates in fowl and events through perinatal development. J. Nutr., 115: 665-674.

Naruhashi, K.; Y. Sai; I.Tamai; N. Suzuki and A. Tsuji (2002). Pept1 mRNA expression is induced by starvation and its level correlates with absorptive transport of cefadroxil longitudinally in the rat intestine. Pharm. Res. (NY), 19:1417-1423. 
Palme, R.; P. Fischer; H. Schildorfer and M.N. Ismail (1996). Excretion of infused 14C steroid hormones via faeces and urine in domestic livestock. Anim. Reprod. Sci., 43: 43-63.

Powell, S.R. (2000). Zinc and health: current status and future directions. The antioxidant properties of zinc. J. Nutr., 130: 1488-1492.

Quarterman, J.; J.N. Morrison and W.R. Humphries (1976). The effects of dietary lead content and food restriction on lead retention in rats. Environ. Res., 12: 180-187.

Quarterman, J. (1987). Metal absorption and the intestinal mucus layer. Digestion, 37: 1-9.

Richard, M.J.; B. Portal; J. Meo; C. Coudray; A. Hadjian and A. Favier (1992). Malondialdehyde kit evaluated for determining plasma and lipoprotein fractions that react with thiobarbituric acid. Clin. Chem., 38: 704-709.

Rommers, J.M.; C. Boiti; G. Brecchia; R. Mejerhof; J.P. Noordhuizen and E. Decuypere (2002). Metabolic adaptation and hormonal regulation in young rabbit does during long-term caloric restriction and subsequent compensatory growth. Anim. Sci., 79: 255-264.

SAS, (2002). SAS/ STAT User's guide statistics. SAS Institute INC., Cary, NC, USA.

Shaheen, A.A. and A.A. Abdel-Fattah (1995). Effect of dietary zinc on lipid peroxidation, glutathione, protein thiols levels and superoxide dismutase activity in rat tissues. Int. J. Biochem. Cell Biol., 27: 89-95.

Song, J.; S.E. Wolf; X.W. Wu; C.C. Finnerty; D.N. Herndon and M.G. Jeschke (2011). Proximal gut mucosal epithelial homeostasis in aged IL1 type I receptor knockout mice after starvation. J. Surg. Res., 169: 209213.

Southon, S.; J.M. Gee; G.E. Bayliss; G.M. Wyatt; N. Horn and I.T. Johnson (1986). Intestinal microflora, morphology and enzyme activity in zinc-deficient and Zn-supplemented rats. Br. J. Nutr., 55: 603-611.

Stevens, C.E. and Hume, I.D. (1995). Comparative Physiology Of The Vertebrate Digestive System, $2^{\text {nd }}$ Ed. Cambridge University press, Cambridge, United Kingdom.

Suda, A.K.; C.S. Pittman; T. Shimizu and J.B. Chambers (1978). The production and metabolism of 3,5,3'-triiodothyronine and 3,3',5'triiodothyronine in normal and fasting subjects. J. Clin. Endocrinol. Metab., 47: 1311-1319. 
Tapiero, H. and K.D. Tew(2003). Trace elements in human physiology and pathology: zinc and metallothioneins. Biomed Pharmacotherapy, Nov; 57(9): 399-411.

Tůmová, E.; L. Zita; V. Skřivanová; A. Fučíková; M. Skřivan and M. Burešová (2007). Digestibility of nutrients, organ development and blood picture in restricted and ad libitum fed broiler rabbits. Archive für. Gefl., 71: 6-12.

Tůmová, E.; Z. Volek; D. Chodová; H. Härtlová; P. Makovický; J. Svobodová;T. A. Ebeid and L. Uhlírová (2016). The effect of 1-week feed restriction on performance, digestibility of nutrients and digestive system development in the growing rabbit. Animal, 10: 1-9.

Wijtten, P.J.; E. Hangoor; J.K. Sparla and M.W. Verstegen (2010). Dietary amino acid levels and feed restriction affect small intestinal development, mortality, and weight gain of male broilers. Poultry Science, 89(7): 142439.

Wu, L.M.; M.H. Hu; X.H. Tong; H. Han and N. Shen (2012). Chronic unpredictable stress decreases expression of brain-derived neurotrophic factor (BDNF) in mouse ovaries: relationship to oocytes developmental potential. PLoS One 7(12): e52331 doi:10.1371/journal. pone. 0052331 [PMC free article] [PubMed].

Zearah, Sameerah A.; S. Hamadie and A.N. Awad (2016). Effect of zinc supplementation on thyroids hormones in sera of diabetic patients type 2 . International Research Journal of Natural Sciences, 4(1): 1-8.

Zhang, S.Y.; J.Z. Wang; J.J.; D.L. Wei and Sui L.I. (2011). Maternal restraint stress diminishes the developmental potential of oocytes. Biol. Reprod., 84: 672-681. 


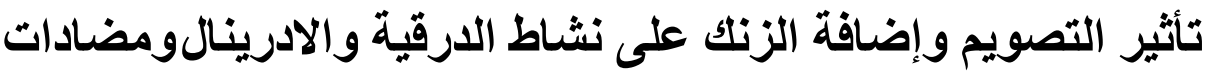 الأكسدة وطول القناة الهضمية في الأرانب النامية فئل}

طحمد السيد السبيعى* ـ محمد عبد العزيز الصاوى**- فيصل بيومى عبد السلام بدرى** - ـ * معهد بحوث الأنتاج الحيو انى ـ مركز البحوث الزر اعية ـ وزارة الزر اعة ـ مصر.

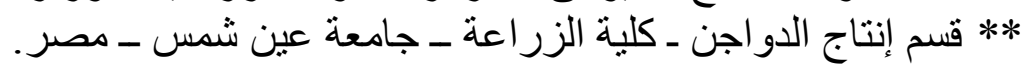

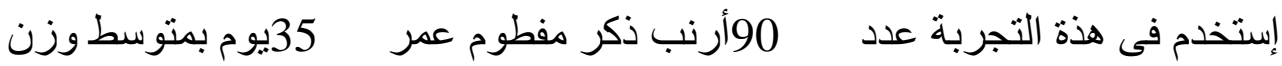

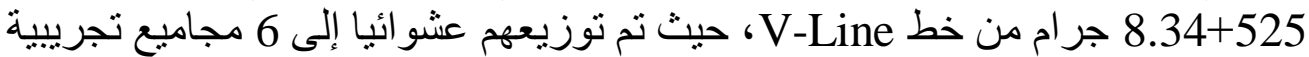
(15) أرنب بكل منها) كالنالى :

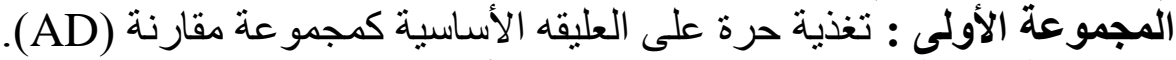

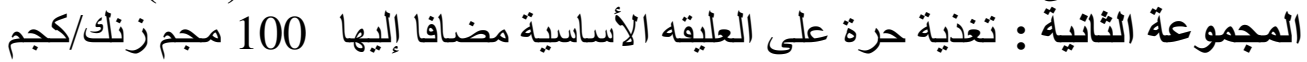
عليقة (Ad+Zn). المجموعة الثالثة: تغذية حرة على العليقه الأساسية مع التصويم لمدة $\quad 24$ ساعة 24 ساعة

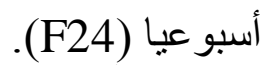
المجموعة الرابعة: تغذية حرة على العليقه الأساسية مع التصويم لمدة 48 ساعة

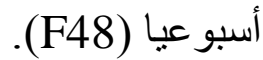

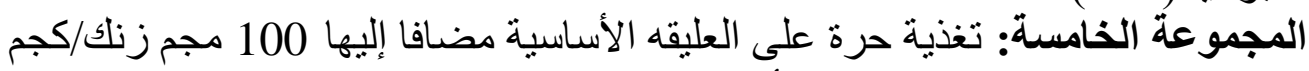

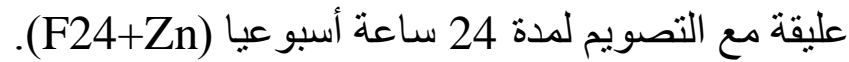

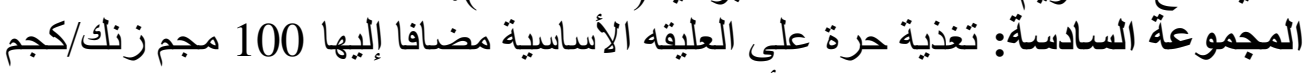
وليقة مع التصويم لمدة 24 ساعة أسبو عيا (F48+Zn). وقد أوضحت النتائج مايلى:

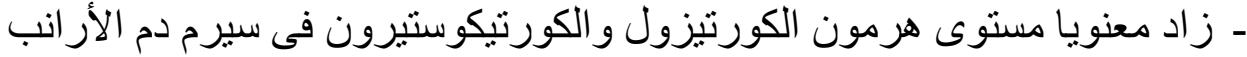

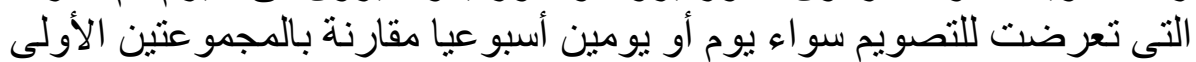

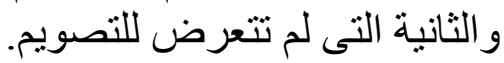

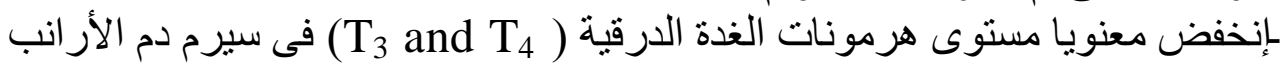

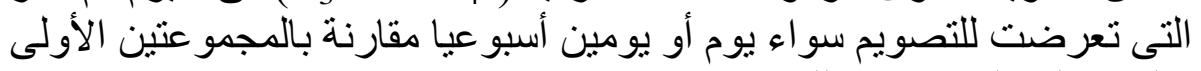

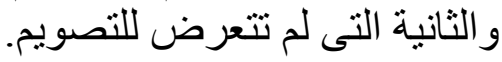


زز اد معنويا مستوى TAC في سيرم دم الأر انب التى تغذت على عليقة مضافا إليها 100 مجم زنكاكتجم عليقة.

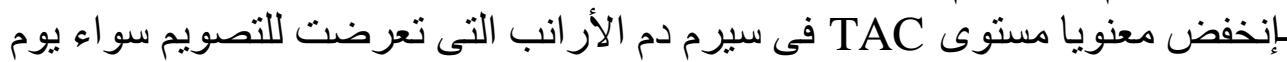

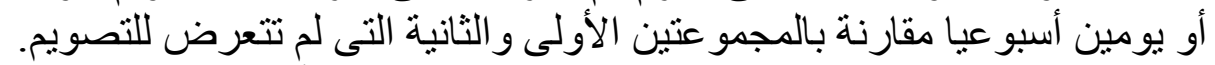

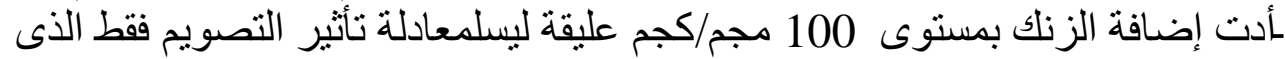

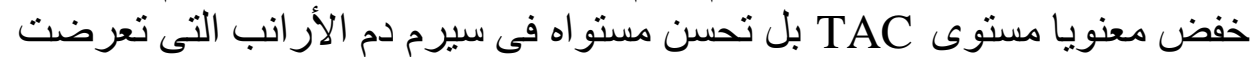

$$
\text { للتصويم سواء يوم أو يومين أسبو عيا. }
$$

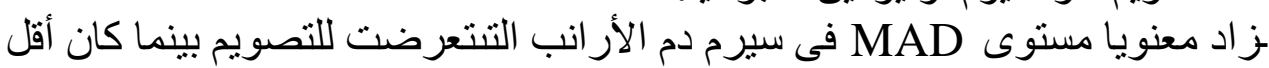
مستوى لل مAD في سيرم دم الأرانب التى تغذت على على عليقة أساسية مضافا إليها

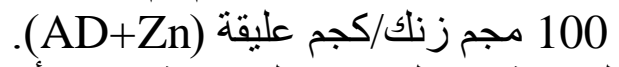

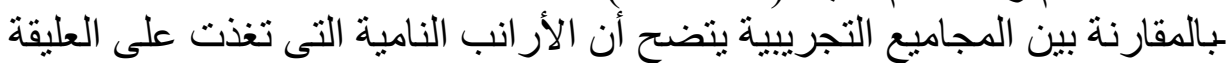

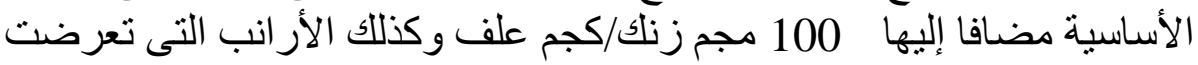

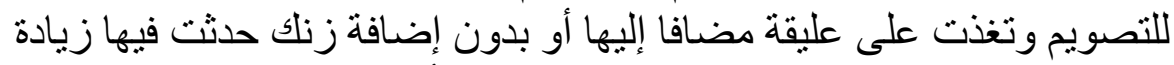

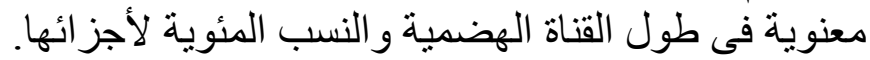

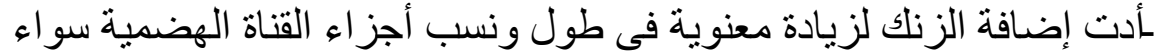

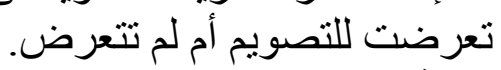
التوصية:التصويم و إضافة|الزنك ل لعليقةالأر انب النامية يؤدى إلى تحسن مستوى

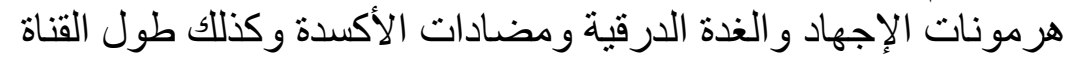

الهضمية ونسب أجز ائها. 